\title{
2,3,7,8-TETRACHLORODIBENZO-P-DIOXIN ALTERS STEROID SECRETION BUT DOES NOT AFFECT CELL VIABILITY AND THE INCIDENCE OF APOPTOSIS IN PORCINE LUTEINISED GRANULOSA CELLS
}

\author{
Olga JABlonsKA ${ }^{1}$, Joanna PiaseCKA-SRAdeR ${ }^{2}$, Anna NynCA ${ }^{3}$, Agnieszka KołOMYCKA ${ }^{2}$, \\ Anna ROBAK ${ }^{4}$, Barbara WĄSOWSKA ${ }^{5}$ and Renata E. CIERESZKO ${ }^{2,3^{*}}$ \\ ${ }^{1}$ Department of Zoology, ${ }^{2}$ Department of Animal Physiology, ${ }^{3}$ Laboratory of Molecular \\ Diagnostics and ${ }^{4}$ Department of Comparative Anatomy, University of Warmia and \\ Mazury in Olsztyn, Oczapowskiego 1A, 10-719 Olsztyn, Poland; ${ }^{5}$ Institute of Animal \\ Reproduction and Food Research, Polish Academy of Sciences, Olsztyn, Poland
}

(Received 14 January 2014; accepted 12 March 2014)

The compound 2,3,7,8-tetrachlorodibenzo-p-dioxin (TCDD), a by-product of human industrial activity, was found to affect ovarian steroidogenesis in animals, but the mechanism of its action is still unclear. The aims of the study were to examine the effect of TCDD on (1) progesterone $\left(\mathrm{P}_{4}\right)$ and oestradiol $\left(\mathrm{E}_{2}\right)$ production by granulosa cells isolated from medium $(3-6 \mathrm{~mm})$ and preovulatory ( $\geq 8 \mathrm{~mm}$ ) porcine follicles, (2) the viability of the cells, and (3) the incidence of apoptosis. Porcine granulosa cells were cultured $(48 \mathrm{~h})$ with or without TCDD $(100 \mathrm{pM}, 100 \mathrm{nM})$. Steroid hormone concentrations in the medium were determined by radioimmunoassay. The viability of granulosa cells was tested spectrophotometrically (alamarBlue ${ }^{\mathrm{TM}}$ assay). Apoptosis was evaluated by flow cytometry using Annexin V and by TUNEL assay. The higher dose of TCDD (100 nM) significantly inhibited $\mathrm{P}_{4}$ and stimulated $\mathrm{E}_{2}$ production by luteinised granulosa cells isolated from medium follicles. The lower dose of TCDD (100 pM) significantly stimulated $\mathrm{P}_{4}$ and inhibited $\mathrm{E}_{2}$ secretion by the cells isolated from preovulatory follicles. None of the two TCDD doses affected cell viability or induced apoptosis in granulosa cells. In conclusion, TCDD directly affected steroid production by granulosa cells obtained from mature pigs, but the effect of TCDD was not due to its cytotoxicity.

Key words: TCDD, annexin V, flow cytometry, TUNEL, apoptosis, steroid secretion, granulosa cells, pig

The compound 2,3,7,8-tetrachlorodibenzo-p-dioxin (TCDD) is a by-product of many industrial processes as well as uncontrolled combustion (Ishimura et al., 2009). Because of its lipophilic properties and slow rate of metabolism, TCDD

*Corresponding author; E-mail: reniac@uwm.edu.pl; Phone: 0048 (89) 524-5283; Fax: 0048 (89) 524-5286 
easily accumulates in the food chain and consequently may be found in human and animal tissues (Larsen, 2006; Bhattaacharya and Keating, 2012). Due to bioaccumulation and resistance to breakdown, TCDD accounts for developmental and reproductive abnormalities in animals (Mandal, 2005). Its toxic effects on the reproductive system include decreased litter size, reduced fertility, endometriosis and altered ovarian function in several animal species (Larsen, 2006; Bhattaacharya and Keating, 2012).

The mechanism of dioxin action is not fully recognised but it appears that, in addition to indirect effects (Jablonska et al., 2011), TCDD may also directly affect the ovary. TCDD is considered to be a potent disrupter of ovarian steroidogenesis in humans (Enan et al., 1996a; Heimler et al., 1998a; Morán et al., 2000, 2003) and rats (Son et al., 1999; Franczak et al., 2006; Shi et al., 2007; Jablonska et al., 2010). In the pig, the toxic effects of TCDD on steroidogenesis have also been reported (Piekło et al., 2000; Gregoraszczuk et al., 2001; Grochowalski et al., 2001). However, the data concerning pigs - an important animal model (Kuzmuk and Schook, 2011) - are inconsistent and based on animals examined during their first oestrous cycle.

It has been reported that TCDD induced apoptosis in human and rat luteinised granulosa cells (LGCs; Heimler et al., 1998a, 1998b), which suggests that similar effects of TCDD may be found in the porcine ovary. Moreover, micromolar doses of TCDD were reported to decrease the viability of rabbit kidney proximal tubule cells (Han et al., 2005) and rat hepatocytes (Turkez et al., 2012). However, the viability of granulosa cells (GCs) treated with TCDD was not studied in pigs, and the issue seems to be worthy of examination since the sensitivity to TCDD is species dependent (Pohjanvirta and Tuomisto, 1994). Thus, the aims of the study were to evaluate the in vitro effects of TCDD on progesterone and oestradiol secretion by LGCs isolated from medium and preovulatory follicles of mature pigs. In addition, the effects on cell viability and the incidence of apoptosis were also examined in the cells.

\section{Materials and methods}

\section{Isolation and culture of granulosa cells}

Porcine ovaries with follicles and corpora albicantia were collected in a local slaughterhouse (Krokowo/Jeziorany or Biskupiec, Poland) and transported (45 min) to the laboratory in cold buffered physiological saline (PBS) supplemented with gentamicin and nystatin. All experimental procedures were approved by the Local Ethics Committee. TCDD (Supelco, USA) was dissolved in dimethyl sulphoxide (DMSO; Sigma-Aldrich, St. Louis, MO, USA), whose final concentration in the culture medium did not exceed $0.1 \%$. The final TCDD concentration in the culture medium was $100 \mathrm{pM}$ and $100 \mathrm{nM}$. The TCDD doses 
have been previously shown to affect in vitro ovarian function in pigs (Piekło et al., 2000; Grochowalski et al., 2001; Jablonska et al., 2011). Solvent controls included $0.1 \%$ DMSO. In order to obtain isolated GCs, follicles from different pigs were used in each experiment.

Ovarian morphology and follicular size were evaluated (Akins and Morrissette, 1968), and GCs were isolated from medium (3-6 mm) and preovulatory ( $\geq 8 \mathrm{~mm}$ ) follicles (Nynca et al., 2009). Cell viability was determined by $0.4 \%$ trypan blue dye exclusion ( $\geq 97 \%$ ) and the cells were resuspended in incubation medium: Eagle's medium with 10\% calf serum (CS; Biomed, Lublin, Poland), $0.05 \mathrm{mg} / \mathrm{ml}$ gentamicin and $60 \mathrm{U} / \mathrm{ml}$ nystatin. Next, the cells were seeded into: (1) 24-well plates, medium follicles: $3 \times 10^{5}$ cells $/ 1 \mathrm{ml}$, preovulatory follicles: $1.5 \times 10^{5}$ cells $/ 1 \mathrm{ml}$ (radioimmunoassay); (2) 96-well plates, $2 \times 10^{4}$ cells $/ 100 \mu 1$ (alamarBlue $^{\mathrm{TM}}$ assay); (3) 8-well glass- or permanox-coated Lab-Tek Chamber Slides, $1 \times 10^{5}$ cells $/ 300 \mu 1$ (haematoxylin-eosin staining and TUNEL analysis, respectively); and (4) 6-well plates, $3 \times 10^{6}$ cells/3000 $\mu 1$ (flow cytometry). After preculture $\left(37^{\circ} \mathrm{C}, 95 \%\right.$ air $\left./ 5 \% \mathrm{CO}_{2}\right)$, cells were cultured (in a medium containing $5 \% \mathrm{CS}$ ) with different treatments according to experiment type.

\section{Hormone assay}

For estimation of $\mathrm{P}_{4}$ and $\mathrm{E}_{2}$ secretion, LGC were preincubated for $72 \mathrm{~h}$ and then cultured for $48 \mathrm{~h}$ with TCDD or DMSO. After culture, the media were collected and stored at $-20^{\circ} \mathrm{C}$. The medium concentration of steroid hormones was measured by a ${ }^{3} \mathrm{H}$-radioimmunoassay (RIA). The validation of this assay for use in experiments with porcine ovarian cells has been reported previously (Ciereszko et al., 1998). Specificity of the anti-progesterone (SO/91/4) and anti-oestradiol antibodies (BS/88/733) is described elsewhere (Ciereszko et al., 2001; Szafrańska et al., 2002). Exogenous treatments did not interfere with the RIA. Intraassay coefficients of variation for $\mathrm{P}_{4}$ and $\mathrm{E}_{2}$ were 3.6 and 5.7\%, respectively. Inter-assay coefficients of variation for $\mathrm{P}_{4}$ and $\mathrm{E}_{2}$ were 3.6 and $3.7 \%$, respectively. Sensitivities of the $\mathrm{P}_{4}$ and $\mathrm{E}_{2}$ assays were 5 and $2 \mathrm{pg} /$ tube, respectively. The experiment was repeated six times and all analyses were performed in triplicate.

\section{Morphology of granulosa cells}

Cells were allowed to attach for 40 hours and then were treated with either TCDD or DMSO (48 h). After culture, the medium was removed and the cells were fixed in $4 \%$ formaldehyde for $25 \mathrm{~min}$ at $4{ }^{\circ} \mathrm{C}$. Morphological analysis was performed by standard haematoxylin and eosin (HE) staining. Morphology of stained GCs was analysed under light microscope (CH30/CH40; Olympus) and images were archived by digital camera (C-5060 WZ; Olympus). 


\section{Viability of granulosa cells}

After 48 hour of preculture, cells were treated with TCDD, staurosporine (STS, $5 \mu \mathrm{M}$, a positive control) or DMSO (48 h). Twenty-four hours prior to the end of culture, alamarBlue ${ }^{\mathrm{TM}}$ reagent (BioSource International, Somerset, NJ, USA) was added at $10 \%$ of the culture volume $(10 \mu 1)$. After culture, the monolayers were assayed spectrophotometrically (570 and $595 \mathrm{~nm}$; Bannerman et al., 2001). A spectrophotometric microtitre well-plate reader (Labsystem Multiscan EX, Finland) was used and calculations were processed according to the manufacturer's directions. Each treatment was examined in four independent experiments, and treatments within each particular experiment were run in quadruplicate.

\section{In situ labelling of nuclear DNA fragmentation}

TUNEL analysis was carried out after preincubation $(40 \mathrm{~h})$ and subsequent culture (48 h) of LGC with either TCDD or DMSO. The BD ApoAlert ${ }^{\mathrm{TM}}$ DNA Fragmentation Assay Kit (Clontech, Mountain View, CA, USA) was used to detect apoptosis-induced nuclear DNA fragmentation via a fluorescence assay at a single cell level. Analysis was performed according to the manufacturer's directions and included appropriate negative and positive controls. Images of cell preparations were recorded for data analysis using a BX51 fluorescent microscope (Olympus, Tokyo, Japan) and digital camera (CC-12 FW, Olympus, Tokyo, Japan). All treatments were run in duplicate and repeated in five (medium follicles) or seven (large follicles) independent experiments. Six images, always from the same precisely defined areas of the TUNEL-stained cell preparations, were taken from each duplicate. TUNEL-positive GCs and the total number of nuclei of GCs in each image were counted and the apoptotic index (number of TUNEL-positive cells/total number of nuclei $\times 100$ ) was calculated.

\section{Annexin V-FITC/propidium iodide double-staining analysis}

Following preculture $(40 \mathrm{~h})$, the cells were cultured (48 h) with TCDD and then stained for apoptosis with FITC Annexin V Apoptosis Detection Kit (BD Pharmingen, San Jose, CA, USA). To characterise the type of cell death, double staining with Annexin V and propidium iodide (PI) was performed on living cells. This method allows for the discrimination of live (Annexin V-FITC ${ }^{-}$and $\mathrm{PI}^{-}$), early apoptotic (Annexin V-FITC ${ }^{+}$), late apoptotic (Annexin V-FITC ${ }^{+}$and $\left.\mathrm{PI}^{+}\right)$and dead $\left(\mathrm{PI}^{+}\right)$cells. After culture with TCDD, GCs were harvested by trypsinisation $\left(0.25 \%\right.$ trypsin, $\left.5 \mathrm{~min}, 37^{\circ} \mathrm{C}\right)$ and centrifuged $(5 \mathrm{~min}$ at $300 \times \mathrm{g})$. The staining procedure was performed according to the manufacturer's recommendations. The samples were analysed by flow cytometry (MoFlo ${ }^{\text {TMXDP, }}$ Beckman Coulter Inc., Brea, CA, USA), which was completed within one hour. Data were collected on at least 50,000 events and analysed using Summit 5.2.0.7477 (Beckman Coulter Inc.) software. 


\section{Statistical analysis}

Data (mean \pm SEM) were analysed by one-way analysis of variance (ANOVA) for repeated measurements followed by the least significant difference post hoc test (Statistica program, StatSoft Inc., Tulsa, OK, USA). Data expressed as a percentage of the number of TUNEL-positive as well as Annexin VFITC-positive cells were arcsine transformed before ANOVA. Differences with a probability of $\mathrm{P}<0.05$ were considered significant.

\section{Results}

\section{Medium hormone concentration}

A higher dose of TCDD $(100 \mathrm{nM})$ decreased $\mathrm{P}_{4}(\mathrm{P}<0.05)$ and stimulated $\mathrm{E}_{2}(\mathrm{P}<0.05)$ secretion by GCs isolated from medium follicles $(\mathrm{n}=6$, Fig. 1$)$. A lower dose of TCDD $(100 \mathrm{pM})$ did not affect $(\mathrm{P}>0.05)$ steroid hormone secretion by the GCs isolated from medium porcine follicles. In contrast, a stimulatory effect of the lower dose of TCDD $(100 \mathrm{pM})$ on $\mathrm{P}_{4}$ secretion $(\mathrm{P}<0.05)$ and its inhibitory effect on $\mathrm{E}_{2}$ secretion $(\mathrm{P}<0.05)$ by porcine GCs harvested from large follicles was observed $(n=6$, Fig. 1$)$.
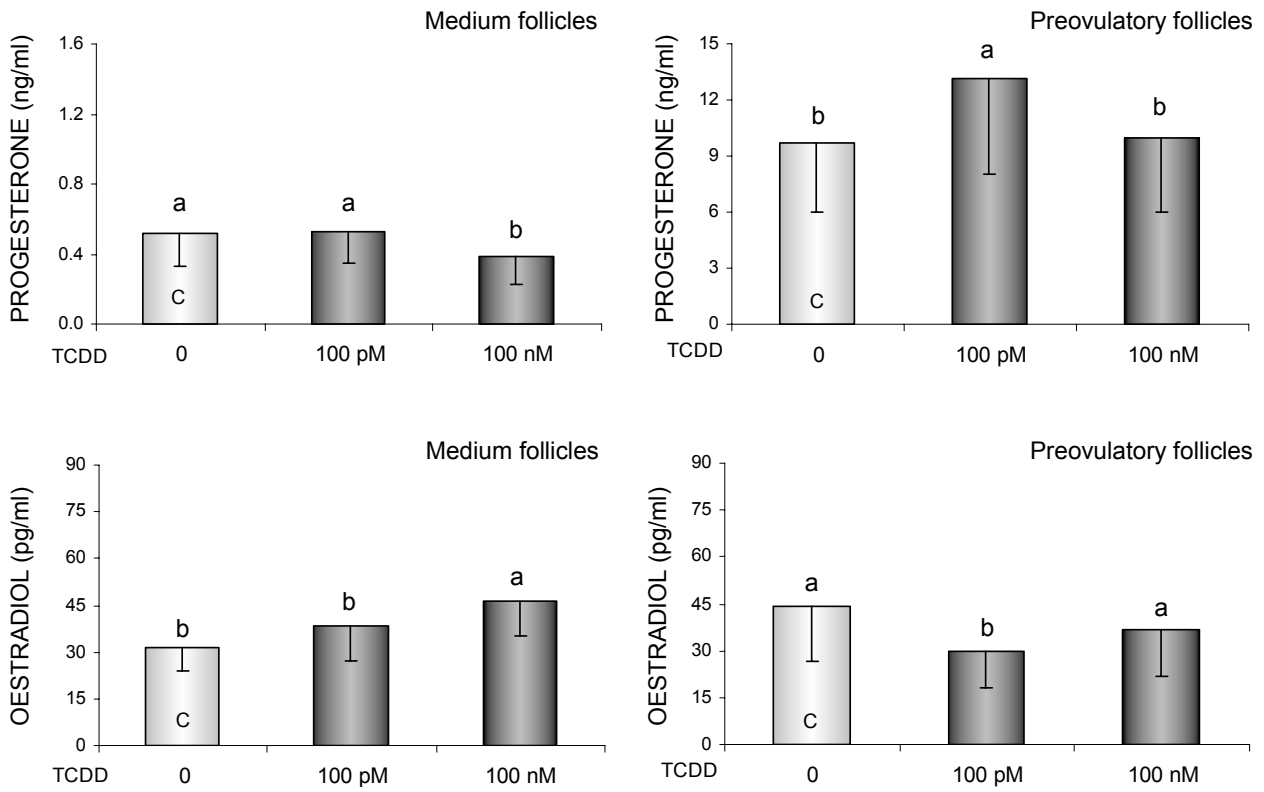

Fig. 1. The effect of 2,3,7,8-tetrachlorodibenzo-p-dioxin (TCDD; $100 \mathrm{pM}, 100 \mathrm{nM}$ ) on progesterone and oestradiol production (mean \pm SEM) by granulosa cells isolated from medium $(n=6)$ and large preovulatory $(n=6)$ porcine follicles. Different superscripts designate significant differences $(\mathrm{P}<0.05)$. C: control (no treatments) 


\section{Morphology and viability of granulosa cells}

Microscopic images of cultured porcine GCs were similar to those described earlier (Stoklosowa et al., 1978). No difference in cell morphology and cell distribution was observed between control (non-treated) and TCDD-treated cells isolated from medium (Fig. 2) and large (data not shown) porcine follicles.
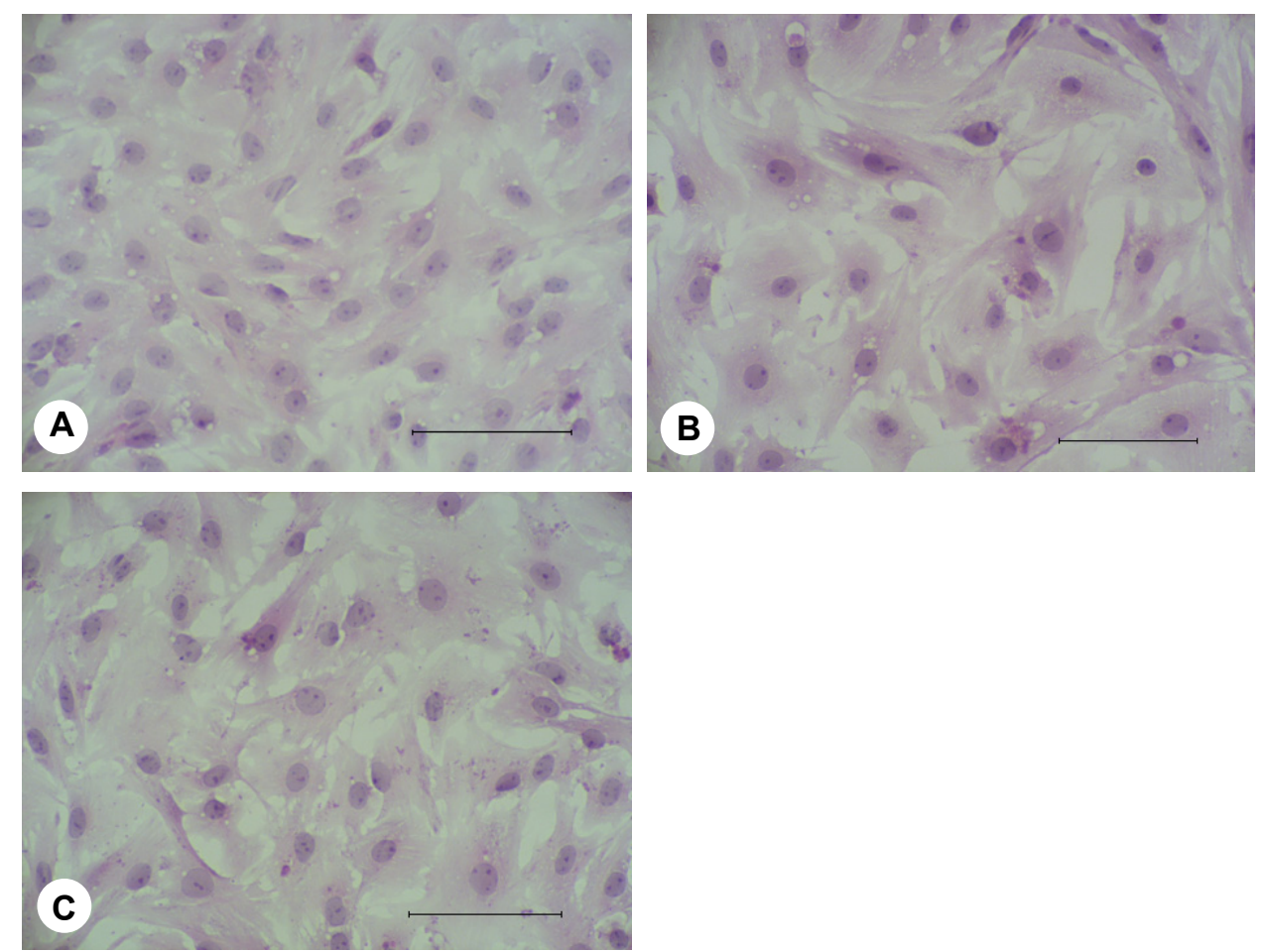

Fig. 2. Exemplary images of haematoxylin-eosin-stained granulosa cells isolated from medium porcine follicles. After culture, the cells were fixed in $4 \%$ formaldehyde and stained. A: untreated cells; B: cells treated with $100 \mathrm{pM}$ of TCDD; C: cells treated with $100 \mathrm{nM}$ of TCDD.

Scale bar: $20 \mu \mathrm{m}$

Neither of the TCDD doses $(100 \mathrm{pM}, 100 \mathrm{nM})$ affected the viability of porcine GCs harvested from either medium (Fig. 3; n =4) or large (Fig. 3; n=4) follicles. A significant decrease $(\mathrm{P}<0.05)$ in cell viability was found only in GCs exposed to a positive control (staurosporine, $5 \mu \mathrm{M}$ ).

\section{The incidence of apoptosis}

The representative images of TUNEL-stained GCs isolated from medium (3-6 mm) follicles are presented in Fig. 4. No difference was found in the apoptotic index between control and TCDD-treated GCs isolated from medium $(n=5)$ as well as large ( $\mathrm{n}=7$; data not shown) porcine follicles. 

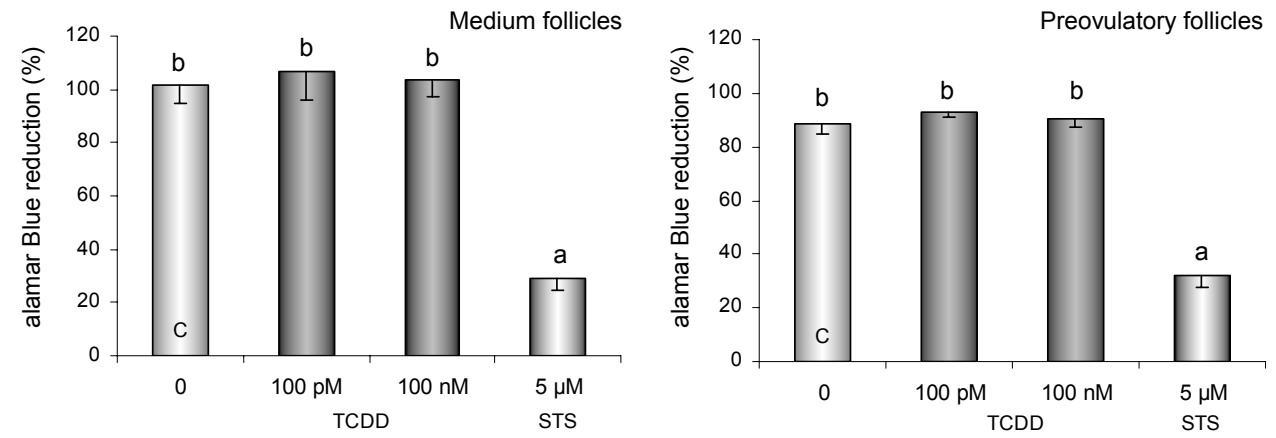

Fig. 3. The effect of 2,3,7,8-tetrachlorodibenzo-p-dioxin (TCDD; $100 \mathrm{pM}, 100 \mathrm{nM}$ ) on the viability of porcine granulosa cells isolated from medium and large follicles assessed by alamarBlue ${ }^{\mathrm{TM}}$ test $(\mathrm{n}=4)$. C: control (no treatments); STS: staurosporine (positive control, $5 \mu \mathrm{M})$. Bars with the same superscripts are not significantly different $(\mathrm{P}>0.05)$

Neither of the TCDD doses $(100 \mathrm{pM}, 100 \mathrm{nM})$ induced cell death (early and late stages of apoptosis, necrosis) in GCs isolated from medium (Fig. $5 ; \mathrm{n}=4$ ) as well as large $(n=4$; data not shown) follicles. The representative dot plots of GCs analysed by flow cytometry are presented in Fig. 5 .

\section{Discussion}

A major regulatory function of ovarian follicles is to create an optimal microenvironment for developing oocytes mainly via the production of steroid hormones. The synthesis/secretion and metabolism of steroid hormones as well as their mechanism of action may be affected by many environmental chemicals, including dioxins. In the current study, we demonstrated that $100 \mathrm{nM}$ of TCDD inhibited $\mathrm{P}_{4}$ secretion and stimulated $\mathrm{E}_{2}$ secretion by LGCs isolated from medium follicles of pigs. In contrast, $100 \mathrm{pM}$ of TCDD stimulated $\mathrm{P}_{4}$ production and inhibited $\mathrm{E}_{2}$ secretion by LGCs isolated from preovulatory follicles of cycling pigs and cultured for $48 \mathrm{~h}$. Previously, it was reported that $100 \mathrm{pM}$ and $10 \mathrm{nM}$ of TCDD did not affect $\mathrm{P}_{4}$ secretion by cultured ( $48 \mathrm{~h}$ ) GCs isolated from large follicles collected from prepubertal pigs (Piekło et al., 2000). In contrast, when the cells were cultured for a considerably longer period (96-144 h), TCDD (100 pM and $10 \mathrm{nM}$ ) inhibited $\mathrm{P}_{4}$ production (Piekło et al., 2000; Grochowalski et al., 2001). Moreover, in the same experiments, the authors demonstrated that exposure of GCs, cultured in the presence of androgens, to $100 \mathrm{pM}$ and $10 \mathrm{nM}$ of TCDD for $48 \mathrm{~h}$ increased (Piekło et al., 2000) or for $96 \mathrm{~h}$ and longer decreased (Piekło et al., 2000; Grochowalski et al., 2001) the level of $E_{2}$. It seems that the range and direction of TCDD effect on porcine granulosal steroidogenesis depend on the source of ovarian follicles (prepubertal vs. mature animals) as well as methodo- 
logical differences (e.g. TCDD dose, length of preincubation time, androgen supplementation in media). It should be emphasised that, regardless of the experimental conditions, TCDD disrupted steroidogenesis in pigs.
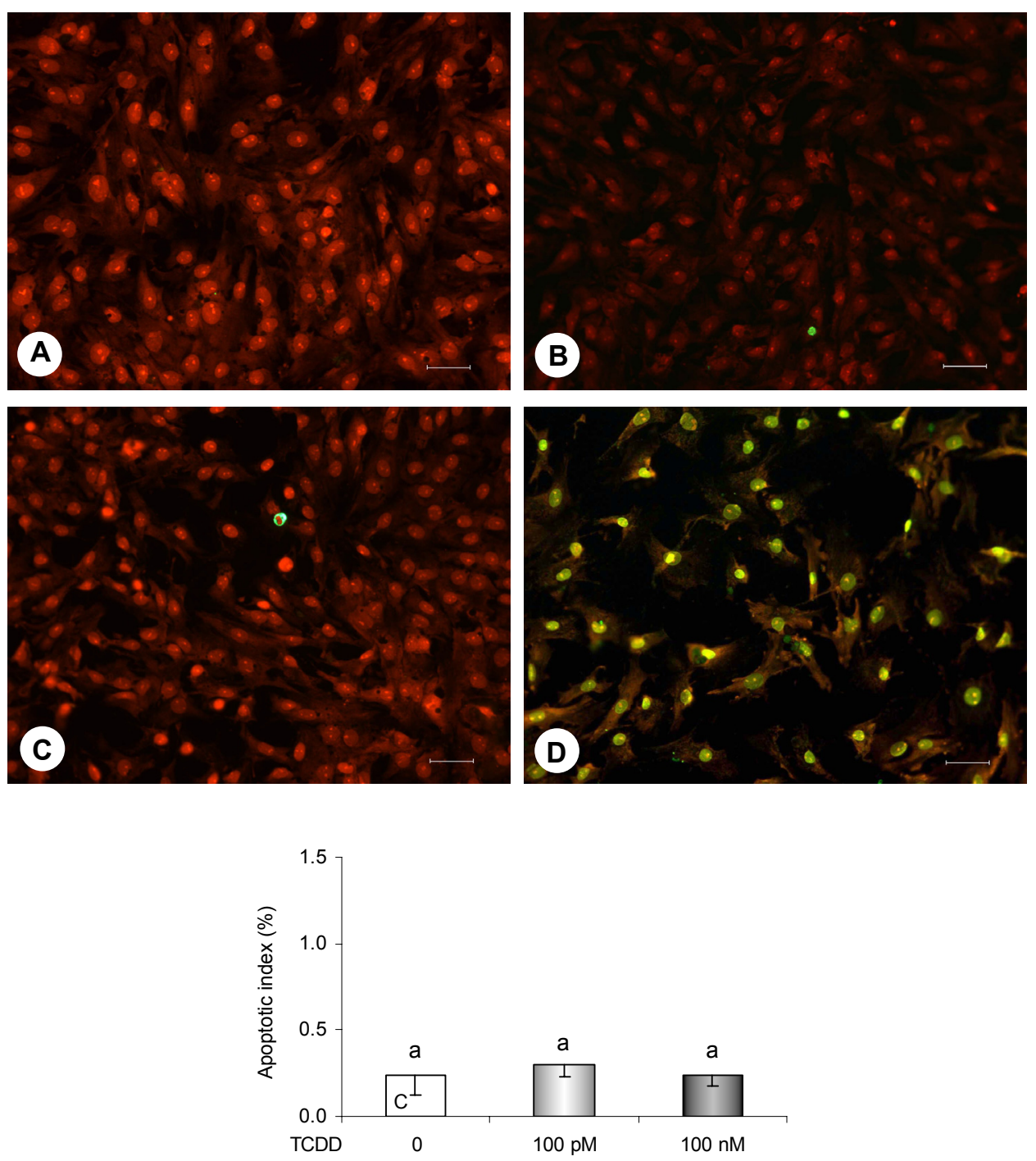

Fig. 4. The effect of 2,3,7,8-tetrachlorodibenzo-p-dioxin (TCDD) on the incidence of apoptosis in cultured porcine granulosa cells isolated from medium follicles $(n=5)$. Upper panel shows representative images of granulosa cells submitted to TUNEL: A: untreated cells; B: cells treated with $100 \mathrm{pM}$ of TCDD; C: cells treated with $100 \mathrm{nM}$ of TCDD; D: cells treated with DNase (positive control). Scale bar: $20 \mu \mathrm{m}$. Lower panel shows the apoptotic index (\%) of granulosa cells treated with TCDD (mean \pm SEM). Bars with the same superscripts are not significantly different $(\mathrm{P}>0.05)$ 

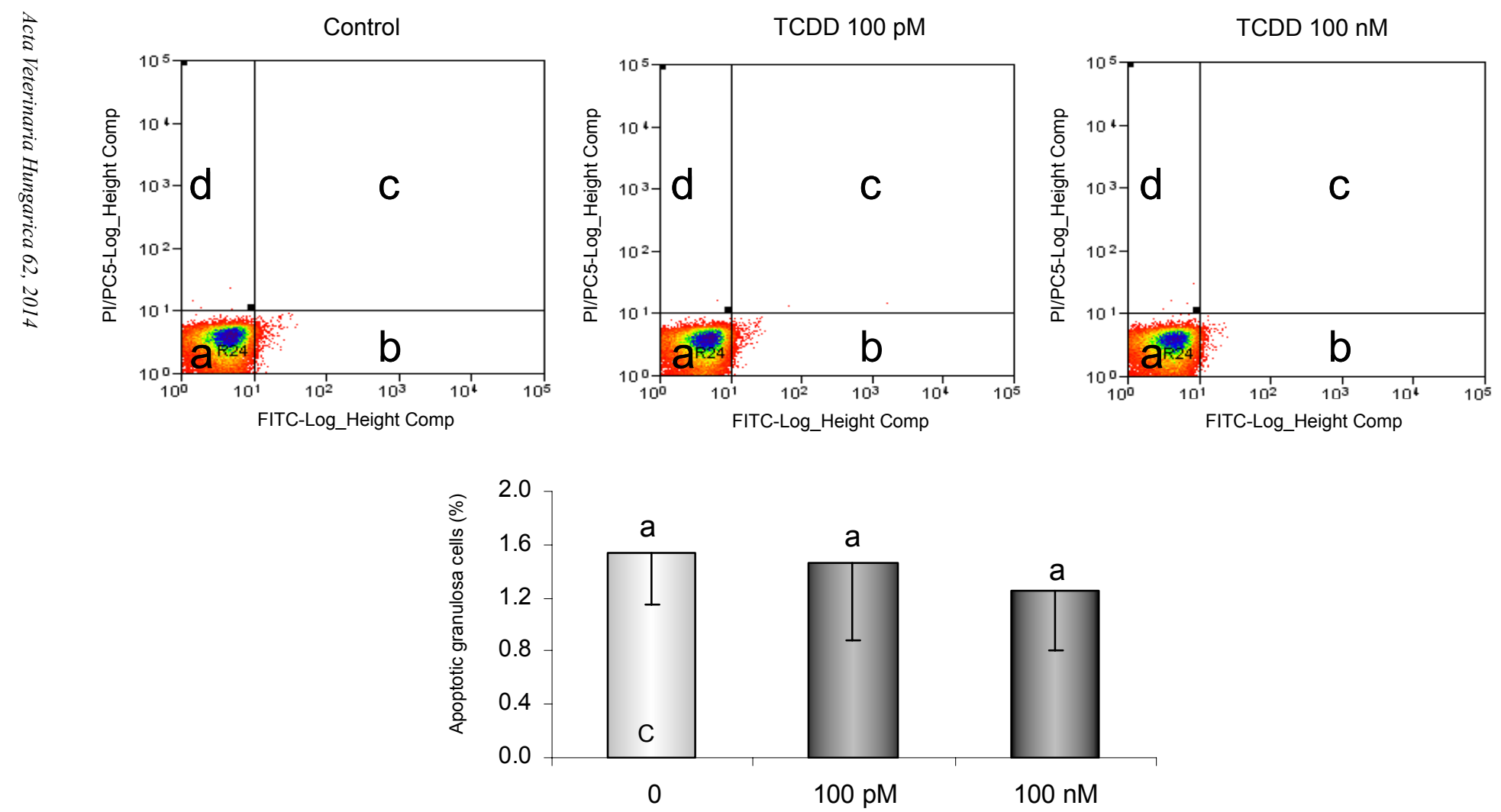

Fig. 5. The effect of 2,3,7,8-tetrachlorodibenzo-p-dioxin (TCDD) on the incidence of apoptosis in cultured porcine granulosa cells isolated from medium follicles $(n=4)$. Upper panel shows representative dot plots of granulosa cells (control and TCDD treated) stained with Annexin V and propidium iodide (PI), and analysed by flow cytometry: a: live cells (Annexin V-FITC $/ \mathrm{PI}^{-}$); b: early apoptotic (Annexin V-FITC ${ }^{+}$) cells;

c: late apoptotic (Annexin V-FITC $\left.{ }^{+} / \mathrm{PI}^{+}\right)$cells; and d: dead cells $\left(\mathrm{PI}^{+}\right)$. Lower panel shows the percentage of early apoptotic (Annexin V-FITC ${ }^{+}$) granulosa cells treated with TCDD (mean \pm SEM). Bars with the same superscripts are not significantly different $(\mathrm{P}>0.05)$ 
The mode of TCDD action on $\mathrm{P}_{4}$ and $\mathrm{E}_{2}$ secretion by porcine LGCs varied depending on whether the source of the cells was medium or preovulatory follicles. This suggests that the stage of porcine follicular development is important for the effect of TCDD on ovarian steroidogenesis. Granulosa cells from preovulatory follicles, in contrast to those isolated from medium follicles, could be exposed in vivo to the preovulatory LH surge. Moreover, preovulatory follicles create a more oestrogenic microenvironment as compared to medium follicles (Foxcroft and Hunter, 1985). Both LH and oestradiol may be responsible for the altered sensitivity of GCs isolated from preovulatory follicles to TCDD.

Despite the documented effects of TCDD on follicular steroidogenesis, the mechanism of TCDD action has not been extensively studied. Inhibitory or stimulatory TCDD effects on porcine steroid production may result from changes either in the steroidogenic cell number or in the cell membrane permeability. Hence, examinations of cell morphology, viability and the incidence of apoptosis were the first steps possibly leading to the elucidation of the TCDD mechanism of action in GCs of pigs. We found that neither 100 pM nor $100 \mathrm{nM}$ of TCDD affected the morphology or viability of porcine GCs harvested from medium and preovulatory porcine follicles. This is in agreement with results from previous in vitro studies performed on human LGCs (Enan et al., 1996b) and rabbit kidney proximal tubule cells (Han et al., 2005), in which similar TCDD doses were studied. Nonetheless, a decreased number of viable cells was reported for rabbit kidney proximal tubule cells (Han et al., 2005) and rat hepatocytes (Turkez et al., 2012) after their treatment with much higher, micromolar doses of TCDD. It appears that pico- and nanomolar doses of TCDD are not cytotoxic to porcine GCs. Cell viability, however, should be tested routinely in all toxicological in vitro studies.

It should be noted that the cell cultures in the current study were supplemented with calf serum (CS, 5\%), necessary for the well-being of cultured cells. However, it was reported that the serum may affect the proliferation and apoptosis of cultured bovine luteal cells (Skarzynski et al., 2007). Since the cells will not grow in a non-supplemented medium, we performed an experiment in which the cells were cultured with CS or bovine serum albumin (BSA, 5\%). It was found that the viability or proliferation of porcine LGCs cultured with BSA was also not affected by TCDD (unpublished data). Staurosporine significantly decreased the viability of both cell cultures. We assumed that the amount of CS in our granulosa cell cultures was not a critical factor affecting the parameters examined.

In the present study, TUNEL assay has been employed to detect apoptotic cells that underwent DNA degradation during the later stages of apoptosis. It was found that TCDD did not cause DNA fragmentation in GCs isolated from medium and preovulatory porcine follicles. The exposure time of GCs to TCDD was possibly too short to induce the late biochemical hallmark of apoptosis, i.e. DNA fragmentation, and what is more, apoptosis may occur in the absence of internucleosomal DNA fragmentation (Cohen et al., 1992). Therefore, the results 
obtained with the TUNEL assay have been verified by the use of flow cytometry and Annexin V as an early marker of the apoptotic cascade activation. Again, neither of the TCDD doses (100 pM, $100 \mathrm{nM})$ were found to induce cell death (early and late stages of apoptosis or necrosis) in GCs isolated from porcine follicles. Data concerning the effect of TCDD on the induction of apoptosis in ovarian follicular cells are very limited. Heimler et al. (1998a) did not find any effects of picomolar $(3.1 \mathrm{pM})$ and nanomolar $(3.1 \mathrm{nM})$ doses of TCDD on DNA fragmentation in human LGCs after $24 \mathrm{~h}$ of culture. However, in the same experiment, nanomolar doses of TCDD after $48 \mathrm{~h}$ of culture as well as micromolar doses of TCDD after both 24 and $48 \mathrm{~h}$ of culture increased apoptosis in human LGCs (Heimler et al., 1998a). The apoptosis level in antral and preantral follicles was not affected in rats exposed to TCDD in utero and lactationally (Heimler et al., 1998b). This discrepancy may be caused by inter-species differences in the sensitivity of GCs to TCDD.

Considering the results discussed above, the effects of TCDD on steroid hormone secretion by porcine GCs cannot be related to the mechanisms affecting cell morphology, viability or apoptosis. TCDD may affect the activity of the enzymes involved in steroidogenesis and production of steroid hormones. However, we found that $100 \mathrm{pM}$ of TCDD did not affect the activity of the cholesterol side-chain cleavage enzyme, $3 \beta$-hydroxysteroid dehydrogenase (3 $\beta$-HSD)/ isomerase and aromatase in GCs isolated from preovulatory porcine follicles (unpublished data). Previously, Gregoraszczuk et al. (2001) found that nanomolar doses of TCDD reduced the activity of both P450scc and 3 $\beta$-HSD in porcine luteal cells. It appears that at present there are no sufficient data to make conclusions concerning the relationship between TCDD and enzymes of steroidogenesis with regard to porcine GCs.

The inhibitory effect of TCDD on $\mathrm{P}_{4}$ and $\mathrm{E}_{2}$ secretion by the porcine GCs might also be caused by the increased metabolism of progesterone and oestradiol. Active hydroxylases were found in GCs isolated from porcine preovulatory follicles (Hammond et al., 1986). In addition, Tritscher et al. (1996) reported a TCDD-induced increase in the activity of hydroxylases in the rat liver. It cannot be excluded that TCDD similarly affects GCs of the pig, although this notion requires further investigation.

In summary, we demonstrated that picomolar and nanomolar doses of TCDD disrupted progesterone and oestradiol secretion by acting directly on LGCs isolated from medium and preovulatory follicles of mature pigs. We also showed that the effect of TCDD on porcine ovarian steroidogenesis was not due to TCDD cytotoxicity. Further studies are required to elucidate the mechanism of TCDD action on ovarian function in pigs. 


\section{Acknowledgements}

This study was supported by The Ministry of Science and Higher Education in Poland (N301 098 31/3017, N N311 317836, N N303 815240, UWM no. 522.0206.0206, 841.0206.0806) and The European Social Fund for O. J.

\section{References}

Akins, E. L. and Morrissette, M. C. (1968): Gross ovarian changes during estrous cycle of swine. Am. J. Vet. Res. 29, 1953-1957.

Bannerman, D. D., Tupper, J. C., Rickets, W. A., Bennet, C. F., Winn, R. K. and Harlan, J. M. (2001): A constitutive pathway protects endothelial cells from lipopolysaccharide-induced apoptosis. J. Biol. Chem. 276, 14924-14932.

Bhattaacharya, P. and Keating, A. F. (2012): Impact of environmental exposures on ovarian function and role of xenobiotic metabolism during ovotoxicity. Toxicol. Appl. Pharmacol. 261, $227-235$.

Ciereszko, R., Opałka, M., Kamińska, B., Wojtczak, M., Okrasa, S. and Dusza, L. (2001): Luteotrophic action of prolactin during the early luteal phase in pigs: the involvement of protein kinases and phosphatases. Reprod. Biol. 1, 63-83.

Ciereszko, R. E., Petroff, B. K., Ottobre, A. C., Guan, Z., Stokes, B. T. and Ottobre, J. S. (1998): Assessment of the mechanism by which prolactin stimulates progesterone production by early corpora lutea of pigs. J. Endocrinol. 159, 201-209.

Cohen, G. M., Sun, X. M., Snowden, R. T., Dinsdale, D. and Skilleter, D. N. (1992): Key morphological features of apoptosis may occur in the absence of internucleosomal DNA fragmentation. Biochem. J. 286, 331-334.

Enan, E., Lasley, B., Stewart, D., Overstreet, J. and Vanedevoort, C. A. (1996a): 2,3,7,8tetrachlorodibenzo- $p$-dioxin (TCDD) modulates function of human luteinizing granulosa cells via cAMP signaling and early reduction of glucose transporting activity. Reprod. Toxicol. 10, 191-198.

Enan, E., Morán, F., Vanedevoort, C. A., Stewart, D., Overstreet, J. and Lasley, B. (1996b): Mechanism of toxic action of 2,3,7,8-tetrachlorodibenzo- $p$-dioxin (TCDD) in cultured human luteinized granulosa cells. Reprod. Toxicol. 10, 497-508.

Foxcroft, G. R. and Hunter, M. G. (1985): Basic physiology of follicular maturation in the pig. J. Reprod. Fertil. Suppl. 33, 1-19.

Franczak, A., Nynca, A., Valdez, K. E., Mizinga, K. M. and Petroff, B. K. (2006): Effects of acute and chronic exposure to the aryl hydrocarbon receptor agonist 2,3,7,8-tetrachlorodibenzo$p$-dioxin on the transition to reproductive senescence in female Sprague-Dawley rats. Biol. Reprod. 74, 125-130.

Gregoraszczuk, E. L., Zabielny, E. and Ochwat, D. (2001): Aryl hydrocarbon receptor (AhR)linked inhibition of luteal cell progesterone secretion in 2,3,7,8-tetrachlorodibenzo-pdioxin treated cells. J. Physiol. Pharmacol. 52, 303-311.

Grochowalski, A., Chrząszcz, R., Piekło, R. and Gregoraszczuk, E. L. (2001): Estrogenic and antiestrogenic effect of in vitro treatment of follicular cells with 2,3,7,8-tetrachlorodibenzo- $p$ dioxin. Chemosphere 43, 823-827.

Hammond, J. M., Hersey, R. M., Walega, M. A. and Weisz, J. (1986): Catecholestrogen production by porcine ovarian cells. Endocrinology 118, 2292-2299.

Han, H. J., Lim, M. J., Lee, Y. J., Kim, E. J., Jeon, Y. J. and Lee, J. H. (2005): Effects of TCDD and estradiol-17 $\beta$ on the proliferation and $\mathrm{Na}^{+}$/glucose cotransporter in renal proximal tubule cells. Toxicol. in Vitro 19, 21-30. 
Heimler, I., Rawlins, R. G., Owen, H. and Hutz, R. J. (1998a): Dioxin perturbs, in a dose- and time-dependent fashion, steroid secretion, and induces apoptosis of human luteinized granulosa cells. Endocrinology 139, 4373-4379.

Heimler, I., Trewin, A. L., Chaffin, C. L., Rawlins, R. G. and Hutz, R. J. (1998b): Modulation of ovarian follicle maturation and effects on apoptotic cell death in Holtzman rats exposed to 2,3,7,8-tetrachlorodibenzo-p-dioxin (TCDD) in utero and lactationally. Reprod. Toxicol. 12, 69-73.

Ishimura, R., Kawakami, T., Ohsako, S. and Tohyama, C. (2009): Dioxin-induced toxicity on vascular remodeling of the placenta. Biochem. Pharmacol. 77, 660-669.

Jablonska, O., Piasecka, J., Petroff, B. K., Nynca, A., Siawrys, G., Wasowska, B., Zmijewska, A., Lewczuk, B. and Ciereszko, R. E. (2011): In vitro effects of 2,3,7,8-tetrachlorodibenzo-p-dioxin (TCDD) on ovarian, pituitary, and pineal function in pigs. Theriogenology 76, 921-932.

Jablonska, O., Shi, Z., Valdez, K. E., Ting, A. Y. and Petroff, B. K. (2010): Temporal and anatomical sensitivities to the aryl hydrocarbon receptor agonist 2,3,7,8-tetrachlorodibenzo- $p$ dioxin leading to premature acyclicity with age in rats. Int. J. Androl. 33, 405-412.

Kuzmuk, K. N. and Schook, L. B. (2011): Pigs as a model for biomedical sciences. In: Rothschild, M. F. and Ruvinsky, A. (eds) The Genetics of the Pig. 2nd edition. CAB International, Wallingford, UK. pp. 426-443.

Larsen, J. C. (2006): Risk assessments of polychlorinated dibenzo-p-dioxins, polychlorinated dibenzofurans, and dioxin-like polychlorinated biphenyls in food. Mol. Nutr. Food Res. 50, $885-896$.

Mandal, P. K. (2005): Dioxin: review of its environmental effects and its aryl hydrocarbon receptor biology. J. Comp. Physiol. B 175, 221-230.

Morán, F. M., Conley, A. J., Corbin, C. J., Enan, E., Vandervoort, C., Overstreet, J. W. and Lasley, B. L. (2000): 2,3,7,8-tetrachlorodibenzo- $p$-dioxin decreases estradiol production without altering the enzyme activity of cytochrome P450 aromatase of human luteinized granulosa cells in vitro. Biol. Reprod. 62, 1102-1108.

Morán, F. M., Lohstroh, P., Vandevoort, C. A., Chen, J., Overstreet, J. W., Conley, A. J. and Lasley, B. L. (2003): Exogenous steroid substrate modifies the effect of 2,3,7,8tetrachlorodibenzo-p-dioxin on estradiol production of human luteinized granulosa cells in vitro. Biol. Reprod. 68, 244-251.

Nynca, A., Jablonska, O., Slomczynska, M., Petroff, B. K. and Ciereszko, R. E. (2009): Effects of phytoestrogen daidzein and estradiol on steroidogenesis and expression of estrogen receptors in porcine luteinized granulosa cells from large follicles. J. Physiol. Pharmacol. 60, 95-105.

Piekło, R., Grochowalski, A. and Gregoraszczuk, E. L. (2000): 2,3,7,8-tetrachlorodibenzo-p-dioxin alters follicular steroidogenesis in time- and cell-specific manner. Exp. Clin. Endocr. Diab. 108, 299-304.

Pohjanvirta, R. and Tuomisto, J. (1994): Short-term toxicity of 2,3,7,8-tetrachlorodibenzo-p-dioxin in laboratory animals: effects, mechanisms, and animal models. Pharmacom. Rev. 46, 483-549.

Shi, Z., Valdez, K. E., Ting, A. Y., Franczak, A., Gum, S. L. and Petroff, B. K. (2007): Ovarian endocrine disruption underlines premature reproductive senescence following environmentally relevant chronic exposure to aryl hydrocarbon receptor agonist 2,3,7,8tetrachlorodibenzo-p-dioxin. Biol. Reprod. 76, 188-202.

Skarzynski, D. J., Shibaya, M., Tasaki, Y., Korzekwa, A., Murakami, S., Woclawek-Potocka, I., Majewska, M. and Okuda, K. (2007): Fas-mediated apoptosis is suppressed by calf serum in cultured bovine luteal cells. Reprod. Biol. 7, 3-15.

Son, D. S., Ushinohama, K., Gao, X., Taylor, C. C., Roby, K. F., Rozman, K. K. and Terranova, P. F. (1999): 2,3,7,8-tetrachlorodibenzo-p-dioxin (TCDD) blocks ovulation by a direct action on the ovary without alterations ovarian steroidogenesis: lack of direct effect on ovarian granulosa and thecal-interstitial cell steroidogenesis in vitro. Reprod. Toxicol. 13, 521-530. 
Stoklosowa, S., Bahr, J. and Gregoraszczuk, E. (1978): Some morphological and functional characteristics of cells of the porcine theca interna in tissue culture. Biol. Reprod. 19, 712-719.

Szafrańska, B., Zięcik, A. J. and Okrasa, S. (2002): Primary antisera against selected steroids or proteins and secondary antisera against $\gamma$-globulins-an available tool for studies of reproductive processes. Reprod. Biol. 2, 187-203.

Tritscher, A. M., Seacat, A. M., Yager, J. D., Groopman, J. D., Miller, B. D., Bell, D., Sutter, T. R. and Lucier, G. W. (1996): Increased oxidative DNA damage in livers of 2,3,7,8tetrachlorodibenzo-p-dioxin treated intact but not ovariectomized rats. Cancer Lett. 98, 219-225.

Turkez, H., Geyikoglu, F., Yousef, M. I., Celik, K. and Bakir, T. O. (2012): Ameliorative effect of supplementation with L-glutamine on oxidative stress, DNA damage, cell viability and hepatotoxicity induced by 2,3,7,8-tetrachlorodibenzo-p-dioxin in rat hepatocyte cultures. Cytotechnology 64, 687-699. 